\title{
Immunosenescence and mucosal immunity: significant effects of old age on secretory IgA concentrations and intraepithelial lymphocyte counts
}

\author{
E Arranz, S O’Mahony, J R Barton, A Ferguson
}

\begin{abstract}
Concentrations of immunoglobulins (Ig) and levels of isotype specific antibodies to three dietary antigens in serum, pure parotid saliva, and in intestinal secretions obtained by whole gut lavage from groups of healthy elderly subjects (aged $>70$ years) and of younger adult controls (aged 25-50 years) were measured. In addition, counts of lamina propria and intraepithelial lymphoid cells were performed in histologically normal jejunal biopsy specimens from elderly and younger subjects. Elderly subjects had significantly higher concentrations of serum and salivary $\operatorname{Ig} A$ and of salivary IgM (both, $\mathbf{p}<0.01$ ), and of salivary IgA antibodies than did the younger subjects, but the amount of immunoglobulin and antibody in whole gut lavage fluid was similar in the two age groups. Jejunal biopsy specimen cell counts showed higher IgA plasma cell counts and lower intraepithelial lymphocyte counts in the elderly group $(p<0.01)$, with similar counts of IgM and IgG plasma cells, eosinophils, and mast cells in the two groups. There is evidence of significant effects of old age on the mucosal immune system.
\end{abstract}

There have been many research studies of ageing and immunity, but they have concentrated on systemic immunity in man or have been conducted in aged rodents. ${ }^{1-3}$ There have been no thorough studies in humans of the influence of ageing on secretory immune function or on intestinal cellular immunity. We report here the results of measurements of immunoglobulins and of isotype specific antibodies to three dietary antigens in serum, pure parotid saliva, and in intestinal secretions obtained by whole gut lavage from a group of healthy elderly subjects (aged $>70$ years) and from younger adult controls (aged 25-50 years). In addition, counts of lamina propria and intraepithelial lymphoid cells were performed in histologically normal jejunal biopsy specimens from elderly and younger subjects.

\section{Methods}

PATIENTS AND VOLUNTEERS

'Elderly' subjects were aged 70 years or more; 'younger' subjects were aged 20-50 years. Some were healthy volunteers. Others were patients who had had full clinical assessment and investi- gation of gastrointestinal symptoms, and in whom the final diagnosis was of functional gastrointestinal symptoms or of a minor clinical problem without evidence of immunological, infectious, neoplastic, or allergic disease. Information was recorded on factors possibly relevant to mucosal immunity, including smoking and alcohol consumption, dietary habits, dentition, and medication.

Series A

For studies on serum and saliva, elderly volunteers were recruited from old people attending the geriatric day centre at the Royal Victoria Hospital and younger subjects from patients of the Gastro-Intestinal Unit at the Western General Hospital, Edinburgh.

\section{Series $B$}

Whole gut lavage fluid was obtained from patients of the Gastro-Intestinal Unit who were having gut lavage with a polyethylene-glycolelectrolyte lavage solution, Golytely, as preparation for barium enema or colonoscopy. If after clinical assessment the final diagnosis was as described above, the patients were included in the study.

\section{Series $C$}

Jejunal biopsy specimens were selected from a file of stored slides, if (i) the patient fell within the age ranges defined, (ii) histology had been reported to be normal by a consultant pathologist, (iii) assays of brush border disaccharidases were normal, and (iv) if review of the case notes showed no evidence, on final clinical appraisal, of immunological or other significant disease as specified above.

\section{SPECIMEN COLLECTION}

\section{Pure parotid saliva}

A timed five minute collection of parotid saliva was obtained after a fast of at least three hours, via a Carlsson-Crittenden cup placed over the parotid duct orifice. ${ }^{4}$

\section{Intestinal fluid}

Whole gut lavage fluid (WGLF) was obtained by giving the patients isotonic non-absorbable polyethylene-glycol-electrolyte lavage solution (Golytely) to a maximum of 4 litres orally after an overnight fast. ${ }^{5}$ Specimens were collected for the study when they became clear, without faecal 
contamination. The specimens were immediately centrifuged and treated with protease inhibitors.

Serum, saliva, and gut lavage specimens were stored in aliquots at $-70^{\circ} \mathrm{C}$.

\section{ELISA TECHNIQUES}

All samples were assayed for total IgA, IgG, and IgM and for specific antibodies of these isotypes to three representative food protein antigens gliadin, ovalbumin, and $\beta$ lactoglobulin, by enzyme linked immunosorbent assays (ELISAs) as previously described. ${ }^{6}$ Reference standards for Ig concentrations were human colostral IgA (Sigma Chemical Co, Poole, Dorset) and a human reference serum for IgG and IgM (Protein Reference Unit, Royal Hallamshire Hospital, Sheffield). Serum from an untreated coeliac disease patient was used as a reference standard for antibodies. Plates were read in an MR580 microELISA reader (Dynatech, Billingshurst, Sussex, UK), set at a wave length of $405 \mathrm{nM}\left(\mathrm{OD}^{405}\right)$, when the standard reached an arbitrarily selected $\mathrm{OD}^{405}$ of $1 \cdot 0$, and antibody levels in test specimens were expressed as a percentage of the optical density of the standard.

The following method was used for measurement of secretory IgA in WGLF: ELISA plates were coated as for total IgA (anti- $\alpha$ chain), and standard colostrum IgA and samples were added in duplicate for overnight incubation; two different conjugates were used including antihuman $\operatorname{IgA}$ (for total $\operatorname{IgA}$, dilution 1:5000) and anti-human secretory component/alkaline phosphatase conjugate (dilution 1:2000) (The Binding Site, Birmingham B15 2SQ, UK). The optical density values obtained for total IgA and secretory component were compared for each gut lavage sample.

\section{JEJUNAL BIOPSY SPECIMENS:}

STAINS AND COUNTING TECHNIQUES

Biopsy specimens from both groups were formalin fixed, embedded in paraffin wax, and stained with:

(i) Haematoxylin and eosin, in order to study the villus/crypt morphology and intraepithelial lymphocyte counts;

(ii) Immunoperoxidase technique to study immunoglobulin containing cells. Briefly, sections were pretreated with trypsin $0 \cdot 1 \%$ in Tris buffered saline $\mathrm{pH} 7.6$ at $37^{\circ} \mathrm{C}$ for 20 minutes, and then serially incubated with primary antibody (sheep anti-human $\operatorname{IgG}, \operatorname{IgA}$,

TABLE I Demographic data of elderly and younger subjects - series $A, B$, and $C$

\begin{tabular}{|c|c|c|c|c|c|c|}
\hline & \multicolumn{2}{|c|}{$\begin{array}{l}\text { Series A } \\
\text { Serum/saliva }\end{array}$} & \multicolumn{2}{|c|}{$\begin{array}{l}\text { Series } B \\
\text { Gut Lavage }\end{array}$} & \multicolumn{2}{|c|}{$\begin{array}{l}\text { Series } C \\
\text { fejunal specimens }\end{array}$} \\
\hline & Elderly & Young & Elderly & Young & Elderly & Young \\
\hline $\begin{array}{l}\begin{array}{l}\text { No } \\
\text { Male/female } \\
\text { Mean age } \\
\text { (range) }\end{array} \\
\text { Smokers } \\
\text { Alcohol } \\
\text { Dentures }\end{array}$ & $\begin{array}{l}43 \\
14: 29 \\
79 \cdot 3 \\
(70-94) \\
14 \\
15 \\
41\end{array}$ & $\begin{array}{l}37 \\
14: 23 \\
36 \cdot 2 \\
(26-50) \\
10 \\
23^{\star} \\
26^{\star \star}\end{array}$ & $\begin{array}{c}16 \\
6: 10 \\
79 \cdot 2 \\
(71-92) \\
2 \\
4 \\
16\end{array}$ & $\begin{array}{l}14 \\
4: 10 \\
32 \cdot 2 \\
(23-47) \\
6 \\
8 \\
1 \star \star\end{array}$ & $\begin{array}{c}27 \\
6: 21 \\
75 \cdot 5 \\
(70-87) \\
7 \\
17 \\
15 / 15\end{array}$ & $\begin{array}{c}25 \\
7: 18 \\
36 \cdot 3 \\
(27-50) \\
9 \\
20 \\
4 / 25\end{array}$ \\
\hline
\end{tabular}

${ }^{\star} \mathrm{p}<0.01 ;{ }^{\star \star} \mathrm{p}<0.001$
IgM at $1: 500,1: 250$, and 1:200 dilutions, respectively); secondary antibody (affinity purified donkey anti-sheep/goat IgG at 1:50 dilution); and tertiary antibody (sheep peroxidase/antiperoxidase at 1:80 dilution). All incubations were carried out in a humid chamber at room temperature for 60 minutes. Antisera were obtained from the Scottish Antibody Production Unit, Carluke, Scotland; positive and negative specificity controls were included in each batch;

(iii) Toluidine blue and carbol chromatrope for mast cells and eosinophils respectively.

Blinded cell counts, on stained sections which had been coded and mixed, were performed with a Leitz microscope, using appropriate eyepieces and graticules, calibrated with a stage micrometer. Villus and crypt length measurements were performed with a $1 \mathrm{~cm}$ linear eyepiece graticule and a $\times 10$ and $\times 40$ objective lens respectively.

Intraepithelial lymphocyte counts were performed by a method previously described ${ }^{7}$ with a $1 \mathrm{~cm}$ square graticule and a $\times 100$ oil immersion lens, expressing the results in numbers of intraepithelial lymphocytes per 100 villus enterocytes.

Counts of plasma cells, mast cells, and eosinophils were performed with the same graticule and eyepiece as for intraepithelial lymphocyte counts. Only well orientated sections were used; fields were examined systematically, starting with the base of the graticule at the muscularis mucosae, counting sequential fields of lamina propria vertically to the luminal surface, then realigning the graticule on the immediately adjacent part of the muscularis mucosae and continuing the process. Epithelium was excluded, and where only part of a field comprised lamina propria, the proportion was estimated by eye. At least 40 lamina propria graticule fields per section were counted. The grid area with a $\times 100$ objective was $0.0132 \mathrm{~mm}^{2}$. The results were expressed as numbers of positive cells $/ \mathrm{mm}^{2}$ of lamina propria tissue.

\section{STATISTICAL METHODS}

Differences in immunoglobulin concentrations, antibody levels, and cell counts were assessed using the Mann-Whitney U test (two-tailed) and correlations with Spearman's rank correlation coefficient. A p value $<0.05$ was considered significant.

\section{Results}

DETAILS OF SUBJECTS

Demographic data for the patients in whom humoral immunity was assessed are summarised in Table I. Sex distribution was similar in the elderly and young groups. Denture use was significantly more common in the elderly, and, in the subjects whose serum and saliva were studied, alcohol use was less frequent than in young subjects.

\section{SERUM IMMUNOGLOBULINS AND ANTIBODIES}

In elderly subjects, the serum IgA concentration was higher and the IgM concentration lower than 
in the young (Table II). Serum concentrations of IgM class antibodies to three dietary proteins were also significantly lower in the elderly than in the young (Table III).

\section{IMMUNOGLOBULINS AND ANTIBODIES IN PAROTID SALIVA}

In pure parotid saliva, IgA concentrations were appreciably higher in the elderly than in the young (Table II). There was a significant positive correlation between the salivary $\operatorname{IgA}$ concentration and age in the elderly group ( $r=0.309$, $\mathrm{p}<0.05$ ). Concentrations of IgM and IgG were also significantly higher in the elderly. Concentrations of IgA class antibody to gliadin, ovalbumin, and $\beta$ lactoglobulin in saliva were high in elderly subjects, and trace amounts of IgG class antibody to two of the three antigens were detected.

\section{WHOLE GUT LAVAGE FLUID}

Studies of intestinal fluid, however, showed no differences in total immunoglobulin concentrations (Table II) or specific antibody values

TABLE II Immunoglobulin concentrations (median (range)) in serum and secretions of elderly and young subjects (Series $A, B$ )

\begin{tabular}{|c|c|c|c|c|c|}
\hline & \multicolumn{2}{|l|}{ Elderly } & \multicolumn{2}{|c|}{ Young } & \multirow[b]{2}{*}{ p Value } \\
\hline & No & Median (range) & No & Median (range) & \\
\hline \multicolumn{2}{|l|}{$\operatorname{Serum}($ series A): } & \multirow{3}{*}{$\begin{array}{l}2737 \cdot 8 \\
(9413-1031) \\
922 \cdot 2 \\
(5498-270) \\
11223 \\
(25490-6090)\end{array}$} & 37 & & $\mathrm{p}<0.001$ \\
\hline $\operatorname{IgM}(\mu \mathrm{g} / \mathrm{ml})$ & 43 & & 37 & \multirow{2}{*}{$\begin{array}{l}2062 \\
(3682-845) \\
1357 \\
(3445-322) \\
10527 \\
(15921-7743)\end{array}$} & $\mathrm{p}<0.05$ \\
\hline $\operatorname{IgG}(\mu \mathrm{g} / \mathrm{ml})$ & 43 & & 37 & & NS \\
\hline \multicolumn{6}{|c|}{ Parotid saliva (series A): } \\
\hline $\operatorname{IgA}(\mu \mathrm{g} / \mathrm{ml})$ & 43 & \multirow{3}{*}{$\begin{array}{l}205 \cdot 4 \\
(3229-30 \cdot 7) \\
1 \cdot 6 \\
(42 \cdot 6-0) \\
1 \cdot 7 \\
(45 \cdot 8-0)\end{array}$} & 37 & \multirow{3}{*}{$\begin{array}{l}113 \cdot 4 \\
(553-216) \\
1 \cdot 1 \\
(5 \cdot 5-0) \\
0 \cdot 5 \\
(34 \cdot 2-0 \cdot 1)\end{array}$} & $\mathrm{p}<0.001$ \\
\hline $\operatorname{IgM}(\mu \mathrm{g} / \mathrm{ml})$ & 43 & & 37 & & $\mathrm{p}<0.05$ \\
\hline $\operatorname{IgG}(\mu \mathrm{g} / \mathrm{ml})$ & 43 & & 37 & & $\mathrm{p}<0.001$ \\
\hline \multicolumn{6}{|c|}{ Whole gut lavage fluid (series B): } \\
\hline $\lg A(\mu \mathrm{g} / \mathrm{ml})$ & & \multirow{3}{*}{$\begin{array}{l}69 \cdot 9 \\
(226-8) \\
3 \cdot 6 \\
(20 \cdot 1-1 \cdot 4) \\
0 \cdot 1 \\
(9 \cdot 8-0)\end{array}$} & 14 & \multirow{3}{*}{$\begin{array}{l}69 \cdot 1 \\
(274-10 \cdot 6) \\
5 \cdot 8 \\
(35 \cdot 8-0) \\
0 \cdot 7 \\
(2 \cdot 1-0)\end{array}$} & NS \\
\hline $\operatorname{IgM}(\mu \mathrm{g} / \mathrm{ml})$ & 16 & & 14 & & NS \\
\hline IgG $(\mu \mathrm{g} / \mathrm{ml})$ & 16 & & 14 & & NS \\
\hline
\end{tabular}

TABLE III Levels of antibodies to three dietary proteins in serum and secretions (median (range)) of elderly and young subjects (Series $A, B$ )

\begin{tabular}{|c|c|c|c|c|c|c|c|c|}
\hline & \multicolumn{4}{|c|}{ Elderly } & \multicolumn{4}{|c|}{ Young } \\
\hline & No & $I g A$ & $\operatorname{Ig} M$ & $I g G$ & No & $I g A$ & $\operatorname{Ig} M$ & $\operatorname{Ig} G$ \\
\hline \multicolumn{9}{|c|}{ Serum antibodies (series $\mathbf{A}$ ): } \\
\hline Gliadin & 43 & $\begin{array}{l}8 \cdot 2 \\
(0-150)\end{array}$ & $\begin{array}{l}39 \cdot 5 \\
(15-155)\end{array}$ & $\begin{array}{l}17 \\
(0-111)\end{array}$ & 37 & $\begin{array}{l}4 \cdot 5 \\
(0-60 \cdot 6)\end{array}$ & $\begin{array}{l}88 \cdot 3^{\star} \\
(14-222)\end{array}$ & $\begin{array}{l}15 \cdot 5 \\
(2 \cdot 6-63)\end{array}$ \\
\hline Ovalbumin & 43 & $(1 \cdot 3-81 \cdot 6)$ & & $\begin{array}{l}23 \cdot 4 \\
(0-98 \cdot 5)\end{array}$ & 37 & $\begin{array}{l}3 \cdot 2 \\
(1-150)\end{array}$ & $\begin{array}{l}21 \cdot 6^{\star \star} \\
(5-49)\end{array}$ & $\begin{array}{l}30 \cdot 5 \\
(2 \cdot 1-37)\end{array}$ \\
\hline$\beta$ Lactoglobulin & 43 & $\begin{array}{l}9 \cdot 3 \\
(2-150)\end{array}$ & $\begin{array}{c}20 \cdot 3 \\
(4-50)\end{array}$ & $\begin{array}{l}36 \cdot 3 \\
(3-108 \cdot 4)\end{array}$ & 37 & $\begin{array}{l}9.2 \\
(0.9-37)\end{array}$ & $\begin{array}{c}29 \cdot 2^{\star \star} \\
(8-90 \cdot 8)\end{array}$ & $\begin{array}{l}29 \cdot 8 \\
(3 \cdot 7-101 \cdot 6)\end{array}$ \\
\hline \multicolumn{9}{|c|}{ Parotid saliva antibodies (series A): } \\
\hline Gliadin & 43 & $\begin{array}{l}11 \cdot 5 \star \\
(1 \cdot 6-81)\end{array}$ & $\begin{array}{l}4 \cdot 5 \\
(0-66)\end{array}$ & $\stackrel{0}{0}(0-5 \cdot 3)$ & 37 & $\begin{array}{l}3 \cdot 8 \\
(0-30 \cdot 4)\end{array}$ & $\begin{array}{l}4 \cdot 6 \\
(0-24 \cdot 5)\end{array}$ & $\begin{array}{l}0 \\
(0-2 \cdot 3)\end{array}$ \\
\hline Ovalbumin & 43 & $\begin{array}{l}15 \cdot 3 \star \star \\
(3 \cdot 4-116 \cdot 7)\end{array}$ & $(0-21 \cdot 3)$ & $(0-6 \cdot 1)$ & 37 & $\begin{array}{c}9 \cdot 1 \\
(0-73 \cdot 5)\end{array}$ & $(0-15 \cdot 5)$ & $(0-7 \cdot 9)$ \\
\hline$\beta$ Lactoglobulin & 43 & $\begin{array}{c}31 \cdot 8^{\star \star} \\
(5-150)\end{array}$ & $\begin{array}{l}1.5 \\
(0-53)\end{array}$ & $\begin{array}{c}0 \cdot 3^{\star} \\
(0-11 \cdot 3)\end{array}$ & 37 & $\begin{array}{l}20.5 \\
(3-101 \cdot 6)\end{array}$ & $\begin{array}{l}1 \\
(0-255)\end{array}$ & $\begin{array}{l}0 \\
(0-0.6)\end{array}$ \\
\hline \multicolumn{9}{|c|}{ Whole gut lavage fluid antibodies (series B): } \\
\hline Gliadin & 16 & $\begin{array}{l}6 \cdot 2 \\
(0-85 \cdot 9)\end{array}$ & $\begin{array}{l}6 \cdot 3 \\
(0 \cdot 5-62 \cdot 8)\end{array}$ & $\stackrel{0}{(0-6 \cdot 5)}$ & 14 & $\begin{array}{l}3 \cdot 2 \\
(0-57 \cdot 8)\end{array}$ & $\begin{array}{l}5 \cdot 3 \\
(0-36 \cdot 2)\end{array}$ & $\begin{array}{l}0 \cdot 3 \\
(0-3 \cdot 3\end{array}$ \\
\hline Ovalbumin & 16 & $\begin{array}{l}3 \cdot 5 \\
(0-71 \cdot 5)\end{array}$ & $\begin{array}{l}1 \cdot 2 \\
(0-5 \cdot 9)\end{array}$ & 0 & 14 & $3 \cdot 3$ & $1 \cdot 6$ & $0 \cdot 5$ \\
\hline$\beta$ Lactoglobulin & & $\begin{array}{l}5 \cdot 3 \\
(1-42)\end{array}$ & $\begin{array}{l}1 \cdot 2 \\
(0-7)\end{array}$ & $(0-3 \cdot 3)$ & 14 & $\begin{array}{l}5 \\
(0-76)\end{array}$ & $\begin{array}{l}2 \\
(0-20 \cdot 6)\end{array}$ & $\begin{array}{l}0 \cdot 2 \\
(0-3 \cdot 6)\end{array}$ \\
\hline
\end{tabular}

${ }^{\star} \mathrm{p}<0.001 ;{ }^{\star \star} \mathrm{p}<0.05$.
TABLE IV Concentration of total IgA and secretory IgA (median (range)) in whole gut lavage fluid from elderly and young subjects (Series B)

\begin{tabular}{lcc}
\hline & Elderly & Young \\
\hline No & 16 & 14 \\
Total IgA $(\mu \mathrm{g} / \mathrm{ml})$ & $189 \cdot 7$ & $186 \cdot 5$ \\
Secretory IgA $(\mu \mathrm{g} / \mathrm{ml})$ & $(470 \cdot 7-11 \cdot 9)$ & $(531 \cdot 2-13)$ \\
SIgA, \% of total & $167 \cdot 6$ & $111 \cdot 4$ \\
& $(439 \cdot 6-14 \cdot 9)$ & $(508-23 \cdot 4)$ \\
& $92-74 \cdot 1)$ & $(100-51)$ \\
\hline
\end{tabular}

when elderly and young subjects were compared. The assay for SIgA concentration in WGLF was developed only recently, and sufficient material for analysis remained from 12 elderly and 12 younger subjects. Values were similar for total IgA, SIgA, and the percentage of IgA as secretory (mean $92 \%$, range $100-74 \cdot 1$ in the elderly group; and mean $80 \%$, range $100-51$ in younger controls) (Table IV).

\section{CELL COUNTS}

The biopsy specimens from elderly and young patients all looked histologically normal; villus and crypt lengths were similar in the two groups. These measurements, and counts of intraepithelial lymphocytes and lamina propria lymphoid cells, are summarised in Table V. In the elderly patients, counts of intraepithelial lymphocytes (expressed per 100 villus enterocytes) were significantly lower $(p<0.04)$ and of lamina propria IgA containing plasma cells significantly higher $(\mathrm{p}<0.01)$ than in the younger controls. Counts of other lamina propria cells (IgG plasma cells, IgM plasma cells, mast cells, eosinophils) were similar in the two groups.

\section{Discussion}

Traditional methods of immunological investigation applied to systemic immunity have clearly shown a phenomenon of immunosenescence..$^{1-3}$ The thymus is atrophic by the age of 60 years and peripheral $\mathrm{T}$ lymphocytes have impairment of proliferative capacity, a reduced secretion of cytokines in response to various signals, and a reduced rate of receptor expression when appropriately stimulated. ${ }^{38-11}$

B cells are intrinsically normal in old age but function in an aberrant way. This is reflected by high concentrations of immunoglobulins in the blood, high titres of various autoantibodies, 1213 and yet an impaired generation of specific antibody in response to antigen encounter. ${ }^{121+}$ Several factors probably contribute to this abnormality of $B$ cells: deficient $T$ cell help and also deficient $T$ suppression of inappropriate function $^{3}$; the fact that after a lifetime of exposure, idiotype/anti-idiotype immunosuppressive loops have formed ${ }^{15}$; or that most B cells are precommitted leaving little capacity for a brisk response to further antigen encounter.

There is general agreement that serum $\operatorname{IgA}$ concentrations are increased in old age in a range of species including man. ${ }^{16} 17$ Previous work on secretory immunity in man in old age has mainly concerned studies with mixed saliva. ${ }^{17}$ These studies can be criticised because no account is 
TABLE V Measurement of villi and crypts, and counts of intraepithelial lymphocytes and lamina propria lymphoid cells, in jejunal biopsy specimens from elderly and young subjects (Series C)

\begin{tabular}{|c|c|c|c|}
\hline Parameter & $\begin{array}{l}\text { Elderly }(n=27) \\
\text { Median (range) }\end{array}$ & $\begin{array}{l}\text { Young }(n=22) \\
\text { Median (range) }\end{array}$ & $p$ Value \\
\hline Villous height $(\mu \mathrm{m})$ & \multirow{8}{*}{$\begin{array}{c}286 \cdot 7 \\
(347 \cdot 5-215 \cdot 3) \\
94 \cdot 2 \\
(132 \cdot 2-63 \cdot 6) \\
17 \cdot 5 \\
(31 \cdot 6-12) \\
744 \cdot 8 \\
(1133-294) \\
244 \cdot 8 \\
(542 \cdot 6-172) \\
28 \cdot 4 \\
(141 \cdot 7-7 \cdot 6) \\
255 \cdot 8 \\
(335-89) \\
190 \cdot 3 \\
(317-22 \cdot 7)\end{array}$} & \multirow{8}{*}{$\begin{array}{c}313 \cdot 6 \\
(490 \cdot 2-208 \cdot 3) \\
96 \cdot 5 \\
(170 \cdot 2-63 \cdot 1) \\
23 \\
(37-15) \\
310 \cdot 5 \\
(680-119) \\
221 \cdot 7 \\
(317 \cdot 6-47) \\
22 \cdot 7 \\
(43 \cdot 5-9 \cdot 4) \\
233 \cdot 6 \\
(337-129 \cdot 5) \\
127 \cdot 3 \\
(302 \cdot 4-38 \cdot 4)\end{array}$} & NS \\
\hline Crypt depth $(\mu \mathrm{m})$ & & & NS \\
\hline $\begin{array}{l}\text { Intraepithelial lymphocytes } \\
\text { (\% enterocytes) }\end{array}$ & & & $\mathrm{p}<0.05$ \\
\hline $\begin{array}{l}\text { IgA-plasma cells } \\
\text { (/mm lamina propria) }\end{array}$ & & & $\mathrm{p}<0.01$ \\
\hline IgM-plasma cells & & & NS \\
\hline IgG-plasma cells & & & NS \\
\hline Mast cells & & & NS \\
\hline Eosinophils & & & NS \\
\hline
\end{tabular}

taken of dentition or dental hygiene so the mixed saliva is likely to be heavily contaminated with crevicular fluid.

In this report we present an essentially descriptive study, a first attempt to identify any gross aberrations of secretory immune function in elderly humans. We have made use of volunteer healthy old people to study serum and pure parotid saliva, and material which has become available from old people, in retrospect considered to have essentially normal gastrointestinal tracts, but who have had either whole gut lavage or small bowel biopsy in the course of investigation in a busy gastrointestinal unit.

Absolute concentrations of immunoglobulins and antibodies in a secreted fluid will be influenced by flow rate ${ }^{18}$ as well as by the immunological function of the tissue concerned. This is particularly relevant to the interpretation of our findings of generally higher concentrations of immunoglobulins in the saliva of elderly subjects. This could be explained entirely if salivary flow rate is significantly slower in old people than in younger individuals. There are no data on flow rates of pure parotid saliva in old age, but in a study of mixed saliva, mean flow rates and protein concentrations were similar in groups of individuals aged $26-44$ and $65-83$ years. ${ }^{19}$

We have found that a general increase in IgA production occurs in the gastrointestinal tract as well as in the serum in old age. The pure parotid salivary IgA concentration was appreciably higher in the elderly group, showing a positive correlation between IgA and age. IgM and IgG concentrations were also increased. Although concentrations of IgA in whole gut lavage fluid were similar in old and younger people, IgA plasma cell counts were significantly higher; this method is probably more sensitive as an index of mucosal IgA status than analysis of fluid obtained in the course of standard ward or outpatient lavage bowel preparation. We are now developing an experimental protocol of steady state whole gut perfusion which will allow us to measure the hourly rate of secretion of immunoglobulins and other substances. The present study of whole gut lavage fluid has, however, enabled us to establish that most of the $\operatorname{IgA}$ in intestinal secretions is bound to secretory component - that is, polymeric - and that in this respect the molecular form of $\operatorname{IgA}$ in the secretions in old age is similar to that of the young.

The high concentrations of IgA in serum and saliva are parallelled by high levels of specific antibody of IgA class to three dietary protein antigens, markers of a 'steady state' antibody status of the individuals concerned. Techniques are now available to allow measurement of the kinetics of immune response to a vaccine or other enterically administered antigen and these should now be applied in old people and could be used to test the hypothesis that intestinal stasis and/or changes in colonic flora induce polyclonal synthesis of IgA via immunomodulatory Gram negative bacterial products. ${ }^{20}$ Decreased efficiency of Kupffer cell function could be relevant. ${ }^{20}$

Serum IgM antibody levels to the three food antigens studied were lower in the elderly group, as was the level of IgA antigliadin antibody in serum. These findings are in agreement with a previous report, ${ }^{21}$ although we found serum IgG antibody levels to be similar in the two age groups. Low levels of serum IgM antibody could be clinically relevant, for these have been shown to correlate with a higher frequency of infection with capsulate bacteria. ${ }^{22}{ }^{23}$ Old age does not, however, have a global effect on IgM, as there were similar levels of $\operatorname{IgM}$ and $\operatorname{IgM}$ antibodies in the saliva and gut lavage fluid from old and young subjects.

Our studies of jejunal biopsy specimen pathology showed no evidence of mucosal atrophy in the jejunum of old people; this supports a recent report by Corazza et al. ${ }^{24}$ We have had similar counts for most of the lamina propria cell types studied in biopsy specimens from old and younger people, which adds weight to the significance of the findings that differences emerge for two cell types. A high count of IgA plasma cells has already been discussed. The finding of a low intraepithelial lymphocyte count (expressed as lymphocytes per 100 villus enterocytes) requires confirmation and further follow up in prospectively collected biopsy specimens. It is necessary to use frozen sections for detailed examination of the phenotype of intraepithelial lymphocyte. Further studies should include counts of CD4 and CD8 positive cells; identification of the $T$ cell receptor types (alpha beta or gamma delta) and the presence of activation markers.

It will be particularly interesting if deficiency of a subset of intraepithelial lymphocyte is found, and if this could be linked to the expansion of $\operatorname{IgA}$ locally. This experiment of nature might contribute very useful data to the investigation of whether or not intraepithelial lymphocyte function as locally active suppressor cells. ${ }^{25}$ This work has been supported by grants from the Sandoz
Foundation for Gerontological Research and from the Scottish Foundation for Gerontological Research and from the Scottish
Hospitals' Endowment Research Trust. We thank Mrs J Johnston Hospitals' Endowment Research Trust. We thank Mrs J Johnston
and Mr J Bode for technical assistance, Dr S Walsh for access to and $\mathrm{Mr} \mathrm{J}$ Bode for technical assistance, Dr S Walsh for access to
her patients, and the staff of the GI Investigation suite for their her patients, and the staff of the GI Investigation
invaluable support in the collection of specimens.

1 Makinodan T, Kay MMB. Age influence on the immune system. Adv Immunol 1980; 29: 287-330.

2 Wade AW, Green-Johnson J, Szewzuck MR. Functional changes in systemic and mucosal lymphocyte repertoires with age: an update review. Aging. Immunol Infect Dis 1988; 1: 65-97. 
3 Thoman ML, Weigle WO. The cellular and subcellular basis of immunosenescence. Adv Immunol 1989; 46: 221-61.

4 Barton JR, Riad M, Gaze MN, Maran AGD, Ferguson A Mucosal immunodeficiency in smokers, and in patients with epithelial head and neck tumours. Gut 1990; 31: 378-82

5 O'Mahony S, Barton JR, Crichton S, Ferguson A. Gut lavage: a new approach to the study of intestinal humoral immunity. Gut 1990; 31: 1341-4.

6 O'Mahony S, Arranz E, Barton JR, Ferguson A. Dissociation between systemic and mucosal humoral immune responses in coeliac disease. Gut 1991; 32: 29-35.

7 Ferguson A, Murray D. Quantitation of intraepithelial lymphocytes in human jejunum. Gut 1971 ; 12: 988-94.

8 Peterson WJ. Immunity, age and loss of immunohomeostasis. Gerontology 1984; 3: 259-69.

9 Antonaci $S$, Jirillo E, Bonomo L. Immunoregulation in aging. Diagn Clin Immunol 1987; 5: 55-61.

10 Brill S, Kukulansky T, Tal E, Abel L, Polgin Y, Dassa C, et al Individual changes in $T$ lymphocyte parameters of old human subjects. Mech Ageing Dev 1987; 40: 71-9.

11 Nagel JE, Chopra RK, Powers DC, Adler WH. Effect of age on the human high affinity IL-2 receptor of PHA-stimulated peripheral blood lymphocytes. Clin Exp Immunol 1989; 75 : 286-91.

12 Felser JM, Raff $M J$. Infectious diseases and aging: immunologic perspectives. 7 Am Geriatr Soc 1983; 31: 802-7.

13 Hiijmans W, Radl J, Bottazzo GF, Doniach D Autoantibodies in highly aged humans. Mech Ageing Dev 1984; 26: 83-9.

14 Saltzman RL, Peterson PK. Immunodeficiency of the elderly. Rev Infect Dis 1987; 9: 1127-39.

15 Goidl EA, Choy JW, Gibbons JJ, Weksler ME, Thorbecke GJ Siskind GW. Production of auto-antiidiotypic antibody during the normal immune response. VIII. Analysis of the cellular basis for the increased auto-antiidiotype antibody production in aged mice. $\mathcal{F} E \times p$ Med 1983; 157: 1635-45.

16 Buckley CE, Buckley EG, Dorsey FC. Longitudinal changes in serum immunoglobulin levels in older humans. Proc Soc Exp Biol Med 1974; 33: 2036-9.

17 Finkelstein MS, Tanner M, Freedman ML. Salivary and serum IgA levels in a geriatric outpatient population. $\mathcal{f}$ Clin Immunol 1984; 4: 85-91.

18 Brandtzaeg P. Human secretory immunoglobulins-VII. Concentrations of parotid IgA and other secretory proteins in relation to the rate of flow and duration of secretory relation to the rate of flow and duration
stimulus. Arch Oral Biol 1971; 16: 1295-310.

19 Ganguly R Oropharyngeal tract host defenses in aging. In: Part B. Mestecky J, McGhee JR, Bienenstock J, Ogra PL, eds. Recent advances in mucosal immunology. New York:

20 Horan MA, Fox RA. Ageing and the immune response - a unifying hypothesis? Mech Ageing Dev 1984; 26: 165-81.

21 Scott H, Rognum TO, Midvedt T, Brandtzaeg P. Age-related changes of human serum antibodies to dietary and colonic bacterial antigens measured by an enzyme-linked immunosorbent assay. Acta Path Microbiol Immunol Scand. [C] 1985; 93: 65-70.

22 Phair JP, Hsu CS, Hsu YL. Ageing and infection. In: CIBA Foundation Symposium, 1988; 134: 143-59.

23 Peterson WJ. Immunity, age and loss of immunohomeostasis. Gerontology 1984; 3: 259-69.

24 Corazza GR, Frazzoni M, Gatto MRA, Gasbarrini G. Ageing and small-bowel mucosa: a morphometric study.

25 Brandtzaeg P, Sollid LM, Thrane PS, Kvale D, Bjerke K, Scott $\mathrm{H}$, et al. Lymphoepithelial interactions in the mucosal immune system. Gut 1988; 29: i 116-30. 